\title{
İSLAM ÖNCESİ TÜRK KÜLTÜRÜNDE ATEŞ VE ATEŞE HÜKMEDENLER (MADDİ KÜLTÜR İZLERİ IŞIĞINDA)
}

\section{Bahriye Güray GÜLYÜZ*}

ÖZ: Ateşin bulunması ve kontrol edilmesi insanlığın gelişimini dinsel, düşünsel, sosyoekonomik olarak etkileyen, toplumsal yaşayışına yön veren önemli bir unsurdur. Öyle ki bazı inanç sistemlerinde tanrıların hediyesi ya da gazap aracı olarak kabul edilen ateş, başlı başına da bir tapım ve din oluşturacak güce sahip olmuştur. Eski Türklerin de ateşe büyük önem verdikleri, bazı inanışlarını ateş ve onunla ilgili unsurlar etrafında geliştirdikleri anlaşılmaktadır. Ateş ile tanrı, güneş, ocak, alev, 1şık, duman, iyi-kötü ruhlar, hastalık, şifa, ödül, ceza gibi fiziki ve metafizik kavramlarla kurulan bağlantı sayesinde ateş kültü bazen esas bazen ise yardımcı bir unsur olarak Türk inanç dünyası içinde önemli bir yer işgal etmiştir. Ateşin sahip olduğu öneme bağlı olarak yakılış yeri, zamanı, şekli ve nedeni etrafında çeşitli ritüeller gelişmiş, kutsal ateşi yakmak ve kontrol etmek ancak seçilmiş kişilerin yetkisine verilmiş, bu kişiler ateş marifetiyle tanrı ve ruhlardan haber aldıkları gibi saçı, adak, kurban ve ölülerin ruhlarını tanrılara ulaştırmayı başarmışlardır.

Bu çalışmada İslamiyet öncesi Türk kültüründe ateş kavramı etrafında gelişen inanış ve ritüeller ile kutsal ateşi kontrol etme kudret ve yetkisine sahip kişi ve yaratıkların incelenmesi amaçlanmıştır.

Anahtar Kelimeler: Ateş, Ateşin Efendileri, Şaman, Demirci, Mitolojik Yaratıklar

\section{FIRE AND THE RULERS ON FIRE IN THE PRE-ISLAMIC TURKISH CULTURE (IN THE LIGHT OF MATERIAL CULTURE TRACES)}

\begin{abstract}
Finding and controlling of fire is an important element that affects the development of humanity in a religious, intellectual, socioeconomic and social way. So that in some belief systems the fire, which is considered to be the gift of the gods or the means of wrath, has had the power to create itself a religion and worship. It is understood that the ancient Turks attach great importance to the fire and develop some beliefs around fire and elements related to it. Fire cult has sometimes occupied an important place in the Turkish beliefs world as an essential element and sometimes as an auxiliary element thanks to the connection established with physical and metaphysical concepts between fire and god, sun,
\end{abstract}

\footnotetext{
* Dr. Öğr. Üyesi, T.Ü. Edebiyat Fakültesi Sanat Tarihi Bölümü. bahriyeguray@ hotmail.com ORCID; https://orcid.org/0000-0003-1116-6527 
lightning, stove, flame, light, smoke, candle, good-bad spirits, illness, healing, reward and punishment. According to the importance of the fire, various rituals developed around the burning place, time, form and reason but burning and controlling the sacred fire were only given to the authority of the elected people, who have succeeded in reaching the hair, vows, sacrifices and spirits of dead to the gods as they have heard from gods and spirits via fire.

In this study, it was aimed to examine beliefs and rituals that developed around the concept of fire with the people and creatures having power and authority by controlling the sacred fire before pre-Islamic Turkish culture.

Keywords: Fire, Lords of Fire, Shaman, Ironsmith, Mythological Creatures

\section{Giriş}

İnsanların sosyal, ekonomik, ruhsal ve dinsel gelişiminde büyük bir etkiye sahip olan ateşin ilk defa ne zaman ve nasıl kontrol altına alındığı bilinmemekle birlikte, bu büyük devrimin günümüzden 500.000 ile 1.500 .000 yıl öncesinde gerçekleştiği düşünülmektedir ${ }^{1}$. Korunma, 1sınma, avlanma, pişirme, ayrıştırma, birleştirme, alet yapma, haberleşme, defin gibi pek çok teknolojik gelişmenin merkezini teşkil eden ateş, insanoğlunun ruhsal gelişimine de katkı sağlamış; karanlık ve karanlıkla birlikte gelen tehlikelerden daha az korkan insan daha güvende hissetmeye başlamıştır. Ayrıca fiziksel nitelikleri bakımından doğadaki rakiplerinden daha donanımsız ve dezavantajlı olan insanın menüsünün ateşte pişirilen yiyeceklerle çeşitlenmesi de onu fiziksel ve zihinsel olarak avantajlı hale getirmiştir².

Ateş mevhumuyla kurulan bağ, ona dinsel bazı niteliklerin yüklenmesine neden olmuştur. Hemen her kültürde ateş ve yakıldığı ocak kutsal birer unsur olmanın yanında başlı başına bir tanrı/tanrıça ya da tanrının tezahürü olarak kabul edilmiş; ateşin kıvılcımı, koru, dumanı, külü, rengi, çıkardığı ses çeşitli mitolojik anlamlar kazanmış, ateşe türlü kurban, adak ve saçılar sunulmuştur.

İnsanoğlunun ateşi başlangıçta yıldırım, yanardağ ya da orman yangını gibi doğal bir kaynaktan aldığı düşünülmektedir. Bu yakıcı ve öldürücü oluşuma yaklaşarak ondan bir parça alabilenler, birlikte yaşadıkları diğerlerinden ayrı ve ayrıcalıklı bir konuma sahip olmuşlardır. Artık onlar birer seçilmiş, kahraman ya da yasak olanı çalmaya cüret eden karanlık güçlere sahip kişilerdir. Zira insanın ateş hakkındaki ilk genel bilgisi toplumsal yasaklama olup; ateşe dair ilk öğrenilen şey ona dokunmamak

${ }^{1}$ Ahmet Uhri, Ateşin Kültür Tarihi, Dost Kitabevi, 1. Basım, Ankara, 2003, s. 21-22.

${ }^{2}$ Yapılan araştırmalar, insanın sadece yemeklerini pişirerek yemeğe başlamasının bile başlı başına bir evrim tetikleyicisi olduğunu ortaya koymaktadır. Pişirerek yemek ve zenginleşen menünün insan kas, sinir ve zihin gelişimine katkısı hakkında ayrıntılı bilgi için bkz. A. Uhri, age., s. 23. 
İSLAM ÖNCESİ TÜRK KÜLTÜRÜNDE ATES VE ATESSE HÜKMEDENLER (MADDİ KÜLTÜR İZLERİ IŞIĞINDA)

gerektiğidir ${ }^{3}$. Çünkü kendine özgü bir ruhu olduğuna inanılan ateş, onu kontrol edebilen özel kișilerin elinde düzeni ya da döngüyü değiștirebilecek büyüsel bir objedir. Temizleyici, iyileştirici, 1sıtan, koruyan ve dönüştüren ateş, aynı zamanda cezalandırıcı, yakıcı ve yok edici bir unsurdur olarak kabul edilmiştir.

\section{İslam Öncesi Türk Kültüründe Ateş}

Arkeolojik araştırmalar, proto-Türk olarak kabul edilen kabilelerden itibaren ateşin saygınlığına ve ibadet unsuru olduğuna işaret eden veriler ortaya koymaktadır. Türklerin ataları olarak kabul edilen bazı boyların inşa ettiği etrafi surlarla çevrili şehirlerin merkezinde yer alan ve ocaklı olmalarıyla diğer yapılardan ayrılan mekânların "ateş ibadeti" ile alakalı tapınaklar olduğu düşünülmektedir ${ }^{4}$. (Çizim 1)

Eski Türklerin hâkimiyet kurduğu sahanın pek çok farklı dinin yayılma güzergâhı üzerinde yer alması, onların kadim inançlarının ham ya da ilk şeklini tespit etmeyi güçleştirmektedir ${ }^{5}$. Bu durum, ateşin Türk kavimlerinin inanç dünyasındaki yerini tayin etmeyi de zorlaştırmaktadır ${ }^{6}$. Zira Türklerin ateş ile olan dinsel bağ ve ilişkileri bazı kaynaklar tarafından "onurlandırmak" ya da "saygı göstermek" olarak değerlendirilirken başkaları ise bunu başlı başına bir "tanrı" ve "tapınma" olarak aktarmıştır. Örneğin VI. yüzyılda yaşayan Bizanslı Theophylaktos Simokattes Türklerin ateşe olağanüstü derecede sayg1 gösterdiklerini söylerken ${ }^{7}$, VII. yüzyılda Çinli rahip Huan-dzang ise Göktürklerin ateşe taptıklarını, ağacın ateş unsuru olmasına istinaden de ateşe olan saygılarından ahşap sıralara oturmadıklarını bildirmektedir ${ }^{8}$. Türklerin ateşe taptıklarına dair bilgilere İslam kaynaklarında da rastlanmaktadır. Kazvini bazı Türklerin yıldızlara

${ }^{3}$ Gaston Bachelard, Ateşin Psikanalizi, Çev. Aytaç Yiğit, Bağlam Yayıncılık, 1. Basım, Ankara, 1995, s. 16.

${ }^{4}$ Emel Esin, İslamiyetten Önceki Türk Kültür Tarihi ve İslama Giriş (Türk Kültürü El-Kitabl, II, Cild I/b'den Ayrı Basim), Edebiyat Fak. Matbaası, İstanbul, 1978, s. 28.

${ }^{5}$ Gumilöv'e göre Türklerin organize bir kavim olarak ortaya çıktığı süreçte, Altay mıntıkasında animizm ve totemizmle karışık atalar kültü olmak üzere başlıca iki dini sistem görülmektedir. Bkz. Lev Nikolayeviçen Gumilöv, Eski Türkler, Çev. D. Ahsen Batur, Birleşik Yayıncılık, İstanbul, 1999, s. 122. Bununla birlikte Maniheizm, Budizm, Mazdaizm, Zerdüştlük, Hıristiyanlık ve nihayet İslamiyet de gerek münferit gerekse kitlesel bazda Türkler arasında yayılabilmiştir.

${ }^{6}$ Türklerin ateşi kutsal saymalarının nedenleri üzerinde farklı görüşler ortaya atılmıştır. F. Ratsel'in ateşin kutsallaştırılmasını Zerdüştlük menşeli bulmasına karşın, Gumilöv Türklerin ateşe tanrı olarak değil, kötü ruhları bertaraf eden bir büyü unsuru olarak saygı gösterdiklerini ileri sürmektedir. Bkz. L.N. Gumilöv, age., s. 128.

7 İsmail Mangaltepe, Bizans Kaynaklarında Türkler (Menandros Protektor ve Theophylaktos Simokattes), Doğu Kütüphanesi, İstanbul, 2009, s. 157.

${ }^{8}$ L. Ligeti, Bilinmeyen İ̧̧ Asya, Çev. Sadrettin Karatay, TTK., 2. Basım, Ankara, 1986, s. 88. 
bazılarının ise ateşe taptığını ${ }^{9}$, İdrisi de Ezgiş Türklerinin ateşe ve diğer aydınlıklara taptığın $1^{10}$ söylemektedir.

Orta Asya Türk kavimlerinin hayat algısında iki türlü ateş olduğu görülmektedir. Bunlardan ilki, 1sınmak, yemek pişirmek gibi gündelik işlerin halledilmesi için yakılan sıradan "küçük ateş"; ikincisi ise Tanrı ile temaşa ya da ruhlarla iletişim kurmak üzere yakılan kutsal "ulu ateştir". Dügün, ölüm, cülus, kurban ve bayram törenleri ile önemli meseleler hakkında fal maksatlı yakılan ulu ateş, muayyen bir zamanda Baş Şaman tarafindan çakmak taşıyla tutuşturulur ${ }^{11}$, bu ateş aracılığıyla mevcut durum göklere bildirilirdi. Bir kurban verildiğinde, kurbanı Tanrıya ya da ruhlara ulaştırma işini de yine ulu ateş üstlenirdi. Örneğin, Beltir Türkleri kurban etinin pişeceği ulu ateşi yabancıların giremediği kutsal bir kayın ormanında, doğu istikametinde; konuklara ikram edilecek yemeklerin pişirileceği küçük ateşi ise batıda yakar, tanrının payı ulu ateş marifetiyle iletilirdi ${ }^{12}$.

Hemen her coğrafyada görülen ateş yoluyla defin geleneğinin Türkler tarafından da uygulandığı, bazı boyların ölülerini yaktıkları anlaşılmaktadır ${ }^{13}$.

Türklerin önemli bayramlarını gece ve gündüz yakılan büyük ateşlerle kutladıkları bilinmektedir. Nevruz Bayramı ile Ergonekon'dan çıkış törenleri

\footnotetext{
${ }^{9}$ Ramazan Şeşen, İslam Coğrafyacılarına Göre Türkler ve Türk Ülkeleri, TTK., 2. Basım, Ankara, 2001, s. 148.

${ }^{10}$ R. Şeşen, age., s. 118.

11 İnsanoğlunun ürettiği ilk ateşi vurma ve sürtme teknikleriyle yaktığı bilinmektedir. Birinci yöntemde birbirine vurulan iki çakmak taşından elde edilen kıvılcımlarla aradaki yanıcı maddeler tutuşturulurken ikinci teknikte ise iki ucu sivriltilmiş bir ahșap çubuk ahşap bir zemin üzerinde döndürülerek aradaki yanıcı malzemelerin tutuşturulması sağlanmaktadır. İnsan eliyle elde edilen ilk ateşin ortaya çıkarılma şekli unutulmamış ve taklit edilerek kadim kutsiyeti devam ettirilmiştir. Taş ve ağaç unsurlarıyla ateş arasında kurulan bağa istinaden bazı toplumlarda çakmak taşları bazılarında ise ağaç parçalarıyla yakılan ateş mukaddes sayılmıştır.

${ }^{12}$ Bahaeddin Ögel, Türk Mitolojisi (Kaynakları ve Açıklamaları ile Destanlar), Cilt 2, TTK., Ankara, 1995, s. 497, 530-531.

${ }^{13}$ Bazı Türk kabilelerinin ölülerini yakarak defnettiği İslami kaynaklarda da yer almaktadır. Bkz. Ramazan Şeşen, İbn Fadlan Seyahatnamesi ve Ekleri, Yeditepe Yayınevi, 1. Basım, İstanbul, 2010, s. 99,101,103,117,118,124. Yapılan araştırmalar, çok geniş bir coğrafyaya dağılmış halde yaşayan farklı Türk kabileleri arasında değişik defin yöntemleri uygulandığını ortaya koymuştur. J.P. Roux'a göre, farklı gerçekleştiriliş şekil ve seremonileri olmakla beraber Türk boyları cesedin ortadan kaldırılması için gömme, sergileme, yakma ve vahşi hayvanlara terk etmek olmak üzere başlıca dört temel yöntem uygulamaktadır. Bkz. Jean-Paul Roux, Altay Türklerinde Ölüm, Çev. Aykut Kazancıgil, Kabalcı Yayınevi, 1. Basım, İstanbul, 1999, s. 218. Türk kabilelerinin cenaze törenleri hakkında ayrıntılı bilgi için bkz. Jean-Paul Roux, Türklerin ve Moğolların Eski Dini, Çev. Aykut Kazancıgil, Kabalcı Yayınevi, 1. Basım, İstanbul, 2002, s. 274-286.
} 
ateş ayinleriyle kutlanmaktaydı. Cülus törenlerinde büyük ateşler yakmak da eski Türklerde yaygın bir gelenek olup tahta çıkışı göğe ileten ulu ateş büyük bir seremonidir ${ }^{14}$. Muayyen zamanlarda icra edilen bu törenlerden başka Türklerin Kök Luu denen Ejderha takımyıldızına bağlı bir mevsimin başında da ormanları ateşe vererek ayin yaptıkları anlaşılmaktadır ${ }^{15}$.

Ateş, Orta Asya kavimleri arasında kehanet aracı olarak da kullanılmaktaydı. Belirli bir zamanda yakılan fal ateşinin çıkardığ 1 duman, ses ve meydana getirdiği şekillere bakılarak gerçekleşecek olayların niteliği ve neticesine dair kehanetlerde bulunulurdu. Hükümdar için yakılan büyük fal ateşine çeşitli kurbanlar da sunulurdu ${ }^{16}$.

Türklerin hayatında önemli ve ayrıcalıklı bir yere sahip kişi ya da toplulukların kabul, yemin ve geçiş törenlerinin de yanan ateş huzurunda, ocağın başında gerçekleştirildiği anlaşılmaktadır. Muhtelif devirlerde tasvir edilen, şölen ya da toplantı esnasında ocağın başında yapılan sadakat yemini, ant içme ve rütbe merasimleri, Orta Asya Türk sanatının başlıca konularından olmuştur. (Çizim 2)

Türklerin ateşi ekseri eril, ocağı ise dişil nitelikli tahayyül ettikleri görülse $\mathrm{de}^{17}$, ateş ruhunun cinsiyeti konusunda boy ve oymakların farklı tasavvurlara sahip oldukları ateşe hitaben okunan dua ve ilahilerden anlaşılmaktadır. Bazı dualarda "ateş anam", "kayın anam", "melikem" diye hitap edilen ateş ruhu, Yakut yemin törenlerinde ise "büyük babamız ateş" olarak karşımıza çıkmaktadır ${ }^{18}$. Bu durum ateş ve ocak kavramlarının iç içe

\footnotetext{
${ }^{14}$ B. Ögel, age. C. 2, s. 497.

15 Emel Esin, Orta Asya'dan Osmanlıya Türk Sanatında İkonografik Motifler, Kabalcı Yayınevi, 1. Basım, İstanbul, 2004, s. 29, 33-34.

${ }^{16}$ Hükümdar için bakılan fal ateşinde alevlerin yeşilimtırak olması bereket; kırmızı olması savaş; sarı olması hastalık; siyah olması ise hükümdarın ölümüne ya da uzak bir yolculuğa işaret kabul edilirdi. Bkz. Abdülkadir İnan, Eski Türk Dini Tarihi, Milli Eğitim Basımevi, 1. Basım, İstanbul, 1976, s. 43.

17 Ateşi doğal bir kaynaktan alan ve üretmeyi başaran ilk kişilerin toplulukların erkek bireyleri, ateşi besleyerek devamını sağlayanların ise kadın bireyler olabileceği düşünülmektedir. Bu durum ateş ve ocak kavramlarının zamanla cinsiyet kazanmasını etkilemiş olmalıdır. Ocağın gerek şekli gerekse de kadının sorumluluk sahasına dâhil olmas dişilik ve doğurganlıkla bağlantılı kabul edilerek zamanla da mahrem bir kavram halini almasını sağlamış olmalıdır. Bazı Altay-Türk dualarında geçen "Atamızın yaktığı alevli ateş", "Anamızın gömdüğü taş ocak" sözleri, bu savın Türk inanç sistemindeki yansımalarını doğrular görünmektedir.

18 Abdülkadir İnan, Tarihte ve Bugün Şamanizm (Materyaller ve Araştırmalar), TTK., 3. Basım, Ankara, 1986, s. 68-71. Teleütlerin parmak boyundaki sarı bir samur olarak düşündükleri ateş ruhu, Yakut inanışlarına göre kısa boylu ak sakallı bir ihtiyardır. Bkz. Celal Beydili, Türk Mitolojisi Ansiklopedik Sözlük, Çev. Eren Ercan, Yurt Kitap, Ankara, 2004, s. 438.
} 
geçtiğini göstermenin yanında, ateşin tek bir cinsiyete hapsolmadığını, rengine, yoğunluğuna, şekline, çıkarttığı ses ve kıvılcımlara bağlı olarak cinsiyet değiştirdiğini düşündürmektedir. Bütün ocaklar tek ruh ve tek ateş tarafindan temsil edilmediği gibi, her ocağın ayrı bir sahibi ve koruyucu ruhu vardır. Kadim Türk geleneklerine göre ailenin koruyucusu olan bu ruhun soluğu duman, yiyeceği kuru odun, yastığı köz, yorganı kül olup, yatağı kurumla kararmıştır ${ }^{19}$.

\section{İslam Öncesi Türk Kültüründe Ateşe Hükmedenler}

\section{Tanrı}

İnsanoğlunun ateşin menşeine dair kurduğu en eski bağın tanrısal gökyüzüyle ilgili olduğu düşünülmektedir. Zira parlayan güneş, ay ve yıldızlar yerden birer ateş parçası gibi görünmüşs, gökyüzünden düşen yıldırımlar yeryüzünde büyük yangınlara neden olmuştur. Türklerin kendi inanışları etrafında geliştirdikleri kozmik yasalara göre ateş, evrenin beş temel unsurundan biridir. Ateş unsurunun yönü güney ${ }^{20}$; vakti öğle; mevsimi yaz; rengi kızıl; göksel cisimleri "Kızıl Saksağan" denen takımyıldızı, "Odd yultuz" denen Mars ve yazın gökyüzünde tepede görülen Kök-luu yıldızının kalbi Sin yıldızıdır ${ }^{21}$. Gök Tanrı inancı ekseninde yaşayan Orta Asya Türk halklarına göre ateş; gök, güneş, ay, yıldızlar ve 1şıklı dünyanın bir sembolü olup, güneş ile ayın bulunduğu katlardan indirilmiştir. Nitekim bazı şaman dualarında ateşin "Ay ve güneşten ayrılmışsın", "Ülker yıldızı arkadaşın", "Tanrıdan fermanlısın” şeklinde övüldüğü görülmektedir. ${ }^{22}$

İslam öncesi Türk kültüründe ateş, başlangıçtan beri Tanrı'nın kontrolündedir. İlk olarak Tanrı tarafından yakılan ateş, daha sonra insana da öğretilmiştir. Kadim Türk efsanelerinden birine göre; bitkilerle beslenen ilk insanlar ateşe ihtiyaç duymamış, ancak Tanrı Ülgen'in ${ }^{23}$ et yemelerini

19 Yakut Türkleri ateş ruhuna ateşin ve ocağın sahibi ve koruyucusu anlamına gelen "Uotiççi”, Altay Türkleri ise "Od-izi” sözüyle hitap ederdi. Yakut ve Altay Türklerinin ocağın efendisi ateş anayı ak saçlı, yaşlı bir kadın; batı ve kuzeybatı Asya'daki bazı kabilelerin ise küçük bir kız olarak algıladıkları anlaşılmaktadır. Bkz. B. Ögel, age., C. 2, s. 509, 515-518.

${ }^{20}$ Güneşin en tepede göründüğü güney yönündeki durumu "güneşin Türklük/kuvvetli vakti" olarak adlandırılmaktadır. Gögün ve güneşin zirvesi kabul edilen güney, ateş unsurundan başka öğle saati, yaz, sıcaklık, parlaklık, tek sayılar, hükümdar ve erkeklik gibi birinci derecede varlıkları simgelemektedir. Bkz. E. Esin, age., 1978, s. 46; E. Esin, age.,2004, s. 64. ${ }^{21}$ Emel Esin, Türk Kozmolojisine Giriş, Kabalc1 Yayınevi, 1. Bask1, İstanbul, 2001, s. 24-25, 62.

${ }^{22}$ B. Ögel, age., C. 2, s. 523.

${ }^{23}$ Altay Türk kavimlerinin dini-mitolojik inanışlarındaki en önemli yaratıcı ruhlarından biri olan Ülgen, 1şıklı ruhların lideri olarak "1şıklı", "ak" gibi sıfatların yanı sıra "Kurbustan Aka", "Ayaz Kaan" gibi adlarla da anılır. Ülgen, insanlara zararı olmayan, iyilik veren bir tanrıdır. Bkz. C. Belydili, age., s. 589-592. 
İSLAM ÖNCESİ TÜRK KÜLTÜRÜNDE ATEŞ VE ATEŞE HÜKMEDENLER (MADDİ KÜLTÜR İZLERİ IŞIĞINDA)

emretmesinden sonra ateşe gereksinimleri olmuştur. Gökten bir siyah ve bir beyaz taş getiren Ülgen, iki taşı birbirine vurarak kuru otları tutuşturmuş ve "bu ateş, atamın kudretinden taşa düşmüş ateştir" diyerek insanlara öğretmiştir ${ }^{24}$. Ateşi yaratan Ülgen, ocağı da yapıp insanlara vermiştir ${ }^{25}$. Ateşin bulunuşuyla ilgili başka bir Altay efsanesine göre ise; Tengri, çıplak yarattı̆g insanın soğuktan korunup hayatta kalabilmesi için ona ateşi vermek ister. Ancak Ülgen'in üç kızı önce davranıp bir taşla demiri birbirine vurarak ateşi bulur ${ }^{26}$. Yakut Türklerinin geleneklerine göre ise ateş, süt gibi beyaz bir tahta oturan gök tanrısı Ürün-ay-Toyon'un ${ }^{27}$ oğludur. Göklerin üçüncü katında oturan Ulu Toyon, ilk ateşi yeryüzüne göndermiştir ${ }^{28}$. Ateş ile özdeşleşen ocak da eski Türk inancında tanrıça Umay ile birleşmiş, ${ }^{29}$ bazı Türk topluluklarında Umay, "ateş ruhu" olarak da kabul edilmiştir ${ }^{30}$. Orta Asya'nın çeşitli bölgelerinde sivri dilimli bir başlık, taç ya da haleyle gösterilen tasvirlerin tanrıça Umay'a ait olduğu düşünülmektedir (Çizim 3). Zira üçgen şeklinin ateş ve ateş ruhunun en eski ideogramlarından biri olduğu, ocak mabudesi Umay'ın dilimli başlığındaki gibi, üç üçgen alınlıklı taç biçimini alan ateş ideogramının tanrılaştırılan atayı ve ateş ruhu sahibini simgelediği bilinmektedir ${ }^{31}$.

Bütün Orta Asya ve Sibirya mitolojilerinin Tanrı tarafindan gökten indirildiği konusunda birleştiği görülen ateş ${ }^{32}$, Türkler tarafindan göksel bir hediye olarak kabul edilmiştir.

\section{Atalar}

Atalar kültünün çok büyük bir öneme sahip olduğu eski Türk inanç sisteminde ateş de kaçınılmaz olarak bu kültte ilişkilendirilmiştir. Ülgen'in

\footnotetext{
${ }^{24}$ A. İnan, age.,, 1976, s. 42.

${ }^{25}$ B. Ögel, age., C.2, s. 501-502.

${ }^{26}$ Efsanelere göre çok uzun bir sakalı olan Tengri, yürürken sakalına basıp sendeleyince bunu gören kızlar gülüşerek onunla alay eder. Buna çok kızan Tengri “Ülgen'in üç kızı benimle alay ettiler ama ben onlardan çok daha akıllıyım. Bir taşla demiri birbirine vurup ateş çıkaracak akıl onlarda yok" diye homurdanır. Bunu duyan Ülgen'in kızları bu bilgiyi kullanarak ateşi keşfeder. Bkz. Bahaeddin Ögel, Türk Mitolojisi (Kaynakları ve Açıklamaları ile Destanlar), C. 1, TTK., 5. Bask1, Ankara, 2010, s. 55.

27 Yakut mitolojisine göre, göğün en üst katında iki beyaz güneşle yaşayan Ürün-ay Toyon, üçüncü bir güneş yaratarak bunu yerle gögün tam ortasına yerleştirmiş ve böylece de Yakut halklarına 1şı̆̆ı vermiştir. Bkz. C. Beydili, age., s. 592.

${ }^{28}$ B. Ögel, age., C.2, s. 501-502.

${ }^{29}$ Emel Esin, age., 1978, s. 39,53,90,

${ }^{30}$ Yaşar Çoruhlu, Türk Mitolojisinin Anahatları, Kabalcı Yayınevi, 1. Basım, İstanbul, 2002, s. 44.

31 Emel Esin, Türklerde Maddi Kültürün Oluşumu, Kabalcı Yayınevi, 1.Basım, İstanbul, 2006, s. 232, 243.

32 B. Ögel, age., C.1, s. 55.
} 
ateşi "atamın kudretinden taşa düşmüş" olarak tanımlaması da ateş kültü ile atalar kültünün iç içe geçtiğinin bir göstergesidir.

Göktürk efsanelerinden birine göre, soğuk yüzünden büyük sıkıntılar yaşayan Türkler, yarı insan yarı tanrı olarak tahayyül edilen bir atanın ateşi bulması sayesinde 1sınabildikleri gibi yemeklerini de pişirerek yemeye başlamışlardır ${ }^{33}$. Türeyiş efsanelerinde de ateşin keşfine dair inanışlara rastlanmaktadır. Göktürklerin kurttan türediğine dair efsanelerden birine göre, ateşi ilk olarak Türk (T'u-chuch) adlı ata keşfetmiş ve halkını kurtararak onların lideri olmuştur. İnanışa göre, batı Göktürklerin on kabilesini meydana getiren On-Oklar Türk'ün neslinden türemiştir ${ }^{34}$.

Yakutlara göre, dünyanın ortasında insanın ilk atasının da yaratıldığı büyük bir ağaç yer almaktadır. İlk insanın yeryüzüne gönderilmesinden önce onunla konuşan ağaç, dünyada işine yarasın diye ataya su, ateş ve demir vermiştir ${ }^{35}$.

Türklerde aile kavramının Ata'nın yaktığı ateş ve annenin kurduğu ocak anlayışı etrafında temellendiği görülmektedir. Nitekim ateş, Türk ailesi ve toplulukları için birleştirici bir görev üstlenirken, ateşin içinde beslendiği ocak da kutsallık kazanarak ailenin temel sembolü halini almıştır ${ }^{36}$. Ocağın sönmemesi soyun sürdürülmesiyle ilgili olduğundan devamını sağlamak büyük bir önem taşımıştır. Birlikte yaşanılan ev/ocak, ata ocağına dayanmakla değerlendiğinden, Türk töresine göre; kardeşler evlenip yeni evler kurduklarında ailenin en büyüğü eski ateşin korlarını yeni evin ocağına koyup bir ateş yakar, böylece kutsal baba ocağını devam ettirir, en küçük oğul ise eski ateşin sahibi olur ve ateş prensi manasına gelen "Odd-Tigin"37

${ }^{33}$ B. Ögel, age., C.1, s. 54.

${ }^{34}$ B. Ögel, age., C.1, s. 27-28.

${ }^{35}$ B. Ögel, age., C.1, s. 101-103.

${ }^{36}$ Göktürk türeyiş efsanesinde de görüldüğü gibi ateş birlikte yaşanılan insanlar için ailenin atası tarafindan keşfedilmiş, Tanrı Ülgen de ateşi ocakla birlikte göndermiştir. Bu durum, Türk töresinde ocakla ilgili çok sayıda geleneğin oluşmasına neden olmuştur. Türk geleneklerine göre, aile sofrası ocağın karşısında olur ve ilk lokma ya da içkinin yudumu ocağa sunulurdu. Kırgız ve Kazak topluluklarında yeni gelin kayınbabasının evinde yanan ocağa yağ atar ve ata çadırındaki ateşe selam verirdi. Altay Türklerinde, yabancılar ateş kültüyle ilgili törenlere katılamadığı gibi evlenerek başka bir aileye dahil olan kızlar da bu haklarını kaybederdi. Yakut Türklerinde de nikahı kıyılmamış nişanlı kızlar da dahil olmak üzere yabancılar evin ocağının "1şık çizgisi” denen sınırını aşıp, ocağın ateşinden alamazdı. Teleüt Türklerinde ise ev sahibiyle aynı soydan olmayanların ateşin yandığı ocağın karşısında ya da yanında oturması yasaktı. Bkz. B. Ögel, age., C.2, s. 331, 511-512.

37 Türk geleneğinde ailenin en küçük oğlunun ateşle ilinti görülmesinde bazı mitolojik inançların da etkili olduğu anlaşılmaktadır. Örneğin Yakut inanışlarına göre insanlara ateşi getiren Tanrı'nın küçük oğludur. Abakan Tatarlarında ise ateşin koruyucusu küçük oğuldur. Abakan mitolojisine göre yaşlı Yıldırım'ın üç oğlundan büyüğünün adı Güneş, ortancanınki 
sıfatıyla baba evinde oturmaya devam ederek ata ocağını sürdürürdü ${ }^{38}$. Yakut Türklerinde de yeni bir eve ocak yapılırken kurban kesilir ve kanı ocağa sürülüp ateşe serpilirdi ${ }^{39}$.

Aile ocağındaki ateş canlı bir varlık olarak tasavvur edildiğinden beslenmiş, geceleri söndürülmeden uyutulmuş, sabahları uyandırılmıştır. Ateşin sönmesi uğursuzluk sayıldığından ocak daima canlı tutulmuştur. Aile ocağında yanan ateş nasıl yakılırsa yakılsın kutsal kabul edilmiştir ${ }^{40}$.

Ataların doğum yeri ya da ilk yaşam alan ${ }^{41}$ olarak kabul edilen dağlar da ateş kültüyle bağlantılıdır. Göğe doğru yükselişi sembolize eden dağlar, ateşi ortaya çıkarmayı sağlayan taşların yuvası olarak kabul edildiği gibi bazı efsanelere göre tanrısal ateşle ilk temasa geçilen yer olması hasebiyle de ayrı bir öneme sahiptir. Nitekim efsanelere göre kadim ata ilk ateşi bir dağın zirvesinde yakmıştır. Buna bağlı olarak üçgen şeklindeki sivri dağlar, Türkler tarafindan ateş unsurunun simgesi kabul edilmiştir ${ }^{42}$. Orta Asya Türk sanatında üçgen biçimli dağ motifinin halılar ve ayin eşyaları üzerinde sıklıkla kullanıldığı görülmektedir (Çizim 4).

Türk geleneklerine göre Atadan beri ateş ruhunun nefesiyle kararmış olan çadır da kutsaldır. ${ }^{43}$

\section{Şaman}

İnsanlar ile tanrılar, iyi ve kötü ruhlar arasında aracılık yapma gücüne sahip, kudretini göklerden ve büyük ataların ruhlarından alan, büyü ve sihir yapma, tedavi etme özellikleri olan kişiye Kam ya da Şaman denmektedir. Kendine özel yöntemlerle elde ettiği extase halinde ruhunu göklere ya da yeraltına ulaştırabilen şaman, toplumun diğer üyelerinin ulaşamayacağ kutsal bir alana erişme yetkisine sahiptir. İnsanlık durumunu aşarak ateşe hükmeden şaman, közleri yutar, kızgın demire dokunur, yanan ateş üstünde yürüyebilirdi. Ateşe duyarsız olan şaman, ateşin ilk sahibi olarak da kabul edilmiştir ${ }^{44}$. Yakut mitolojisine göre Tanrı tarafından gökyüzünde yaratılan

Ay, en küçügün adı ise Ateş’tir. Sibirya halkları arasındaki yaygın bir inanışa göre de Isıg1 Malan Tengri'nin en küçük oğlunun adı Odkan'dır. Yakut mitolojisinde de Ateş Ruhu olarak kabul edilen Tanrının küçük oğlunun adı Okhon, Aal Okhon ya da Aal Uod İççite'dir. Bkz. C. Beydili, age., s. 437-438.

${ }^{38}$ B. Ögel, age., C.1, s. 28-29; B. Ögel, age., C.2, s. 504.

${ }^{39}$ A. İnan, age., 1986, s. 117-118.

${ }^{40}$ A. İnan, age., 1976, s. 42.

${ }^{41}$ J.P. Roux, Türklerin ve Moğolların Eski Dini, Kabalcı Yayınevi, 1. Basım, İstanbul, 2002, s. 156-159.

${ }^{42}$ E. Esin, age., 2004, s. 28.

${ }^{43}$ A. İnan, age.,1986, s. 68.

${ }^{44}$ J.P. Roux, age, s. 82. 
"İlk Şaman”, sağaltma, uçma gibi yeteneklerinin yanında ateşin içinden sağ çıkabilme, yani ölümsüzlük özelliğine de sahipti ${ }^{45}$. Orta Asya'nın çeşitli bölgelerinde kutsal kabul edilen sahalardaki taşlar üzerindeki, özel kıyafet, başlık ve aksesuarlı çizimlerin şaman tasvirleri olduğu düşünülmektedir. (Çizim 5-6)

Şamanların yaptı̆̆ 1 her törende mutlaka ateş yakılmakta, kurban törenlerinde, hangi ruh için olursa olsun kurban edilen hayvanın bir parçası ateşe atılarak öncelikle ateş ruhuna sunulmaktayd $1^{46}$. Şamanik törenlerin merkezini teşkil eden ateş, aynı zamanda Şamanın kullandığı çeşitli kemik eşyanın ısıtılarak şekillendirilmesinde de kullanılmaktaydı.

Ölülerin ruhlarını kurtarmak şamanın başlıca görevleri arasında yer almaktaydı. Şamanın, göğe yükselişinde "sıcak ruha" ${ }^{47 "}$ " yardım etmek için kullandığı yöntemlerin başında bazen at sırtında, bazen ahşap köşklerde bazen ise tek başına bedeni yakmak gelmekteydi. Türklerde ölü yakma geleneğinin, göğün aydınlık katlarına ulaşmak üzere sıcak ruhun dumana dönüşmesini kolaylaştırmak maksatlı uygulandığı düşünülmektedir ${ }^{48}$. Ruhun kurtuluşu ya da yükselişinde şamanın kullandığı araç ve en büyük yardımcı ateştir. Buna bağlı olarak cesetlerin yakılmadan defnedildiği Türk topluluklarında bile mezar başında ateş ya da mum yakıldığı, mezarlara ateş çıkardığı düşünülen madeni aynalar ${ }^{49}$ yerleştirildiği ya da mezar anıtlarının üzerine ateş ve ateşle ilgili anlam barındıran çeşitli nesnelerin piktogram ve ideogramlarının (Çizim 7) resmedildiği bilinmektedir ${ }^{50}$.

Şamanik inanca göre; kötü ruhları kovan ateş aynı zamanda her şeyi temizlemektedir. Çeşitli hastalıklar, ateşin marazlı bölgeye direkt olarak uygulanması yanında yanan bir bez ya da meşalenin hastanın etrafinda dolaştırılmasıyla da tedavi edilirdi. Hastanın kutsal ateşin dumanını içine çekmesi, külüne dokunması ya da yemesi de bir çeşit şifa kaynağı olarak

${ }^{45}$ C. Beydili, age., s. 261-262.

${ }^{46}$ A. İnan, age., 1986, s. 71.

${ }^{47}$ Çok eski zamanlara dayanan Türklerin yaşamın döngüsel evrimi kuramına göre insan ruhu biri göksel, parlak ve sıcak ruh olan "şang" diğeri ise toprak merkezli, karanlık ve soğuk ruh olan "kuei" olmak üzere iki parçadan oluşurdu. Şang, bedenin üst, kuei ise alt kısmında bulunmaktaydı. Ölüm gerçekleştiğinde, yeniden doğum beklentisindeki kuei ruh, karanlığın geleneksel ikametgâhı olan kuzeydeki sarı pınara doğru giderken şang ruh ise göksel özüne doğru süzülmeye çalışırdı. Bkz. E. Esin, age., 2006, s. 228-229.

${ }^{48}$ E. Esin, age., 2006, s. 237.

${ }^{49}$ Türklerin evren algısındaki kozmolojik ideogramlardan biri olan ayna, göksel ateşin sembollerinden biri olarak kabul edilmektedir. Zira Türkler için eski türkçede bağır közngü denen parlatılmış bakır aynayla yakılan ateş göksel ateşi ifade etmekteydi. Bkz. E. Esin, age., 2001, s. 30.

${ }^{50}$ E. Esin, age., 2006, s. 232, 237, 239-246. 
kullanılmaktayd ${ }^{51}$. Bazı hastalık ya da ruhsal problemlerin de Türkler tarafından ateşle ilgili kabul edildiği anlaşılmaktadır. Örneğin yeni doğum yapmış kadınlara musallat olduğuna inanılan Al Karısı ya da Al Bastı'nın, ateş menşeli bir ruh olduğu düşünülmektedir ${ }^{52}$. Yine bazı Türk toplulukları, boyun ve başlarda çıkan yara ve uçukların ateşe saygısızlık edildiği için peyda olduklarına inandıkları gibi, bu marazların tedavisi de ancak kartaldan türeyen Şamanın çakmak taşıyla yakacağı ateş marifetiyle sağlanırdı ${ }^{53}$. Türk hükümdarlarına gönderilen elçiler de yanan ateşler ya da meşaleler arasından geçirilerek beraberlerinde gelmesi muhtemel kötü ruhlar bertaraf edilmek suretiyle hanın huzuruna çıkarılırdı.

\section{Demirci}

Türkler tarafından "kök-Temür" yani "gök demir"54 olarak adlandırılan demir, üzerine yemin edilebilecek denli kutsal bir nesnedir. ${ }^{55}$ Altay kavimlerine göre; ateşin babası demir, annesi ise taştır. Şamanların ateşe karş1 okuduğu ilahilerde "Senin baban sert çelik, annen çakmaktaşı, ulu ataların ise ak-kavak ağacıdır" 56 şeklindeki betimlemeler sıkça kullanılmaktadır.

Türk inanışlarına göre kutsal ateşe hükmetme gücüne sahip kişilerden biri de dağdaki taşı eritip demiri yapan, ona şekil veren demircidir (Çizim 8). Sürekli ateşle çalışan demirci, doğanın sırlarına hâkim bir sihirbaz olarak da kabul edilmiştir. Öyle ki çoğu Türk topluluğunda şaman ve demirci

\footnotetext{
${ }^{51}$ Hastalık ve mikropların ateşle temizlenmesi Orta Asya halkları arasında alazlama olarak adlandırılan yaygın bir gelenektir. Ölümlerden sonra ölüyle veya ölünün bulunduğu yerle temas etmeleri ihtimaline karşın sadece insanlar değil hayvanlar ve eşyalar da bu yöntemle temizlenirdi. Salgın hastalıklardan sonra Yakut Türkleri meşalelerle evleri ve diğer alanları temizlerken, kuzeyde yaşayan Buryat Moğolları ise hayvanlarını ağılların dokuz yanına yaktıkları ateşlerin üzerinden geçiriyorlardı. Bkz. B. Ögel, age., C. 2, s. 522.

52 B. Ögel, age., C. 2, s. 514-515

${ }^{53}$ A. İnan, age., 1986, s. 119.

${ }^{54}$ Orta Asya Türk dünya algısında "demir" kavramının sabit, düzenli bir döngünün sembolü olarak algılandığı anlaşılmaktadır. Nitekim eski Türk düşüncesine göre gökte hiç kımıldamadan duran, kutlu gökyüzüyle yeryüzünü birleştiren aynı zamanda da Tanrı ile insanı ayıran Kutup Yıldızı, gögün direği olarak kabul edilmiş ve "Demir Kazık", "Demir Ağaç" veya "Demir Direk" adlarıyla anılmıştır. Bkz. B. Ögel, age., C. 2, s. 170.

${ }^{55}$ B. Ögel, age., C. 1, s. 67; E. Esin, age., 1978, s. 97. Koruyucu bir t1lsım ve muska olarak da kabul edilen demir, bu özelliğine bağlı olarak Şaman kıyafetlerinde kullanıldığı gibi yeni doğum yapan anne ve bebek de kötü ruhlardan korunmak için demir objeler taşırd. Demirci, insanlara, özellikle de lohusalarla yeni doğan bebeklere kötülük getiren Albastı ruhunun en büyük düşmanı olarak kabul edilirdi. Bazı Türk boylarının demir parçalar ya da çekiçlerle "Demirci geldi!" diye bağırarak Albastı'yı korkuttukları öğrenilmektedir. Bkz. A. İnan, age., 1986, s. 84 .

${ }^{56}$ B. Ögel, age., C. 2, s. 498.
} 
kavramlarının iç içe geçtiği görülmektedir. Yakutlara göre şaman ve demirci aynı yuvadandır ${ }^{57}$. Buryat halkına göre; Ak Şaman ve Kara Şaman olmak üzere iki tip şaman olduğu gibi, Ak Demirci ile Kara Demirci olmak üzere iki türlü de demirci vardır ${ }^{58}$. Demircinin kullandığ 1 ocak, kerpeten, çekiç, örs, körük gibi alet ve edevat kutsal sayılır, (Çizim 10) bunların her birinin koruyucu ruhları olduğuna inanılırd ${ }^{59}$.

Demircilerin kendilerine özgü ateş merkezli erginlenme ayinleri olduğu anlaşılmaktadır. Yakut demircileri, demircilerin koruyucu ruhu olan Kıtay Baksı Toyon şerefine kırmızı bir inek keser, ineğin kanını çekiç, örs, kerpeten gibi çeşitli demirci aletleri üzerine sürer, ineğin ciğeri ve yüreğini demir ocağında kızarttıktan sonra örse koydukları ciğeri yok oluncaya kadar çekiçle döverlerdi ${ }^{60}$. Buryat demirci ayinlerinden birinde ise karnı açılarak kalbi çıkarılan bir at, göksel demirci Boşintoy'a (Çizim 9-10) kurban edilir, bizzat Boşintoy'un yerine geçen demirci, insanları uygarlaştırsınlar diye oğullarını dünyaya nasıl gönderdiğini anlatırdı. Ayin, Boşintoy'u temsil eden demircinin diliyle ateşe dokunması ya da erimiş demiri tutmasıyla sonlanırd1 ${ }^{61}$.

Demircilerin Türk halkları için ne denli önemli olduğu Ergenekon Destanı'nda da vurgulanmıştır. Efsaneye göre Ergenekon'da sıkışıp kalan Türk ulusunu hapsolmaktan kurtaranlar, dağın içindeki demiri eritip geçit açan demircilerdir. Türk kavimleri bu önemli olayı yaşatmak üzere yeni yılın başladığı gece, ateşler eşliğinde bir tören düzenler; demircilerin Ergenekon' dan çıkarken kullandıkları körüklerle ocaklar hazırlanır, bir parça demir ateşte iyice 1sıtılarak örste çekiçlerle vurularak uzatılırd1 ${ }^{62}$.

Demircilik mesleği ile savaşçılık da iç içe geçmiştir ${ }^{63}$. Alpleri koruyan zırh ve kalkanlarla, büyük zaferler kazanmalarını sağlayan ama aynı zamanda ölümlerine de neden olan silahlar demircinin eseridir. Yakut mitlerine göre demirci, mesleğini cehennemin baş demircisi kötü tanrı K'daai Maksin'den öğrenmiştir. Ateş kıvılcımlarıyla çevrelenmiş demirden bir evde oturan büyük usta K'daai Maksin, savaşçı kahramanların kırılmış ya

${ }^{57}$ J.P. Roux, age., s. 82.

${ }^{58}$ B. Ögel, age., C. 1 , s. 69.

${ }^{59}$ B. Ögel, age., C. 1, s. 68.

${ }^{60}$ B. Ögel, age., C. 1 , s. 68.

${ }_{61}$ M. Eliade, Demirciler ve Simyacılar, Çev. Mehmet Emin Özcan, Kabalcı Yayınevi, İstanbul, 2011, s. 88.

62 B. Ögel, age., C. 1, s. 64.

${ }^{63}$ Türkçede demirci manasına gelen "tarkan", aynı zamanda kahraman ve yalnız atlı savaşçı anlamlarını da taşımaktadır. Bkz. M. Eliade, age., s. 90. Tarkan unvanı, hükümdar tarafından verilen önemli bir saygı rütbesi olup töreye göre tarkanlar vergi vermez ve ceza görmez, tarkan rütbesi nesilden nesile aktarılırd1. Bkz. B. Ögel, age., C. 1, s. 69. 
da kopmuş uzuvlarını tamir etmektedir ${ }^{64}$. Yine Yakutların kutlu demircilerinden biri olan Çiki aynı zamanda savaş̧̧ıların da eğitmenidir ${ }^{65}$.

Sadece ticari bir iş olarak görülmeyen demircilik mesleği, Türkler tarafından yüksek ve öncelikli bir toplumsal mertebeye yerleştirilmiştir ${ }^{66}$. Yakut topluluklarında kamlığa geçiş törenleri esnasında edilen yemininde şaman, Yakut ulusuna kudretli demirciler bahşeden Kitay Baksı Toyon'a sayg1 göstereceğine, demirci hastalanırsa kızıl inek kesip kurban sunacağına ve kurbanın ciğerleriyle böbreklerini demircinin ocağına gömeceğine ant içmektedir ${ }^{67}$. Yakut Türkleri dünyanın ortasından geçerek gökyüzüne dek uzanan kutsal bir demir ağaca inanmaktadır. Yer ile göğü birleştiren bu ağaç aynı zamanda ilk insanın da yaratıldığı yerdir. Ağaç, dünyaya gönderilmeden evvel ilk ataya su ve ateşle birlikte demiri de vermiştir ${ }^{68}$. Yakutların en önemli demircilerinden biri, adı koruyucu, muhafız, aile ocağı ve kutsal ateş gibi kavramları da ifade eden Ağl sözcügünden gelen Ağlıs'dır ${ }^{69}$.

\section{Hayvanlar ve Mitolojik Yaratıklar}

Özel ve seçili insanların dışında bazı hayvanlarla mitolojik yaratıkların da ateşe hükmetme özelliği olduğu görülmektedir. Bir Altay anlatısına göre; yüce Tengri'ye kadar ulaşmayı başaran bir kurbağa, ateş yakmanın sırlarını öğrenmiş ve bir dağdan aldığı taş ve Hış ağacından aldığı kav parçasıyla ilk ateşi yakıp insanlara öğretmiştir ${ }^{70}$. Yakutlara göre; göğün üçüncü katında oturan Ulu Toyon, ilk ateşi bir ateş kargasıyla yeryüzüne göndermiş ${ }^{71}$, başka bir Yakut efsanesine göre ise taşları birbirine vuran bir kartal yeryüzünü kaplayacak büyüklükte bir ateş yakmış, yangını görmeye gelen insanlar da buna bakarak çakmak taşlarıyla ateş yakmayı öğrenmiştir. Bazı Altay anlatılarına göre; Korbolko adlı kuş insanların toplandıkları bir yerde ateşin nasıl yakılacağını onlara öğretmiştir ${ }^{72}$.

\footnotetext{
${ }^{64}$ M. Eliade, age., s. 87.

${ }^{65}$ M. Eliade, age.,s. 87. Cengiz Han'ın doğum adı olan Temürdjin yani Timuçin, klasik Moğolcadaki temür yani demirden türetilmiş olup demirci manasına gelmektedir. Bkz. J.P. Roux, age., s. 83.

${ }^{66}$ Türk törelerine göre demircilik bir ata mesleği olarak kabul edilerek geliştirilmiştir. L.N. Gumilöv'un değerlendirmesine göre; göçebe topluluklar arasında sadece Türkler demire hükmetmeyi başarmış, buna bağlı olarak da bir millet olarak Türklerin umumi tarih sahnesine çıkışları demir dökümcülüğündeki ustalıklarıyla başlamıştır. Bkz. L.N. Gumilöv, age., s. 101102.

${ }^{67}$ A, İnan, age., 1986, s. 78.

${ }^{68}$ B. Ögel, age., C.1, s. 101-103.

${ }^{69}$ B. Ögel, age., C.2, s. 504.

${ }^{70}$ B. Ögel, age., C.2, s. 500.

${ }^{71}$ B. Ögel, age., C.2, s. 501-502.

72 B. Ögel, age., C.2, s. 499-500
} 
Türk kültüründe ateş unsurunu sembolize eden kuşlardan biri de kargaya benzeyen gerçek bir kuş olan saksağandır. Türkler tarafından kızıl sagızgan olarak adlandırılan bu kuş, göğün zirvesini ve güney yönünü temsil ettiği gibi, ateş unsuruyla bağlantılı bir yıldız kümesi de Türk kozmolojisinde aynı adla anılmaktadır ${ }^{73}$.

Erken Çin ve Proto-Türk devirlerinden beri gök tanrısının timsali kabul edilen yırtıcı kuşlar, ana yönlerle temel unsurların renklerine ilişkin geleneklere göre siyah, sarı ya da kırmızı renklerde tasvir edilirdi. Nitekim proto-Türk olarak kabul edilen Chou'ların (MÖ. 1050-249), bayrakları üzerinde yer alan kuzgunu, beyaz zemin üzerine ateş ve güneş kırmızısı olarak resmettikleri anlaşılmaktadır ${ }^{74}$. Eski Türkler tarafından parlak kırmızı ve altına çalan kırmızı rengi ifade etmek üzere kullanılan kızıl, aynı zamanda ateşi sembolize etmektedir ${ }^{75}$.

Ateşle ilgili olduğuna inanılan mitolojik yaratıkların en önemlilerinden biri, tanrıça Umay'la ilintili kabul edilen ve Türkler tarafından Hüma Kuşu olarak da adlandırılan Feniks'tir ${ }^{76}$. Orta Asya kültürlerinde güneşin doğuşunu, hayat döngüsünü, yeniden doğuşu, ölümsüzlüğü sembolize eden uğurlu bir kuş olan Feniks, genellikle parlak renkli büyük bir boyun ve kanatlara sahip, çok uzun ömürlü olarak düşünülmüş̧ür. Öyle ki yaşadığı ömrün bitimine yakın alev alev yanmaya başlayan bu kutsal ateş kuşu, yok olmak yerine kendi küllerinden yeniden doğar ${ }^{77}$.

Ateş unsuruyla alakalı başka bir mitolojik hayvan da ateşte yanmayan ya da ateşte yaşayan bir yaratık olan Semender'dir. Türk kültürüne dışardan geldiği kabul edilen semender, birbirinden çok farklı görünümlere sahip olarak tahayyül edilmiştir. Doğu halklarının efsanelerine göre küçük gövdeli uzun gagalı bir kuş olan semender, ömrünün belli bir kısmını tamamladığında uçma yeteneğini kaybedip yüksek bir dağdaki yuvasına çekilir. Kanatlarını çırparak inleyen semenderin vücudu alev alır ve yanıp küle döndükten sonra külün altından mavi bir yumurta oluşur. Kırk gün sonra bu yumurtadan çıkan yavru, atalarının döngüsünü tekrar ederek semendere dönüşür ${ }^{78}$. Kanatsız bir ejder, kertenkele ya da sıçana benzeyen, beyaz ve tüylü bir yaratık olarak da tarif edilen semender, inanışa göre;

${ }^{73}$ E. Esin, age., 2004, s.26, 119-120, 152.

${ }^{74}$ E. Esin, age., 2004, s.204.

${ }^{75}$ E. Esin, age., 2004, s. 106. dn. 186. Kızıl rengin hayvanlar için kullanılmasında aşırılık, güç ya da hile ifade ettiği düşünülmektedir. Bkz. Y. Çoruhlu, age., s.187.

${ }^{76}$ C. Beydili, age., s. 249.

${ }^{77}$ Yaşar Çoruhlu, Türk Sanatında Hayvan Sembolizmi, Seyran Kitap, 1. Baskı, İstanbul, 1995, s. 29.

${ }^{78}$ C. Beydili, age., s. 491. 
İSLAM ÖNCESİ TÜRK KÜLTÜRÜNDE ATES VE ATESSE HÜKMEDENLER (MADDİ KÜLTÜR İZLERİ IŞIĞINDA)

ateşin içine girer ve orada kıpkırmızı olana kadar kalır. Ateşin içinden çıkınca beyazlayana kadar bekler ve tekrar ateşe koşarak suyun içinde görülmeyen bir balina gibi kaybolur ${ }^{79}$.

Mitolojik bir hayvan olan ejderha, Türk kültüründeki Çin menşeli figürlerden biri olarak değerlendirilmektedir. Gök ve yer ibadetiyle bağlantılı olan ejderha, Gök luu ve Yer luu olmak üzere iki mahiyetli düşünülmüştür. Türkçe Kök luu olarak adlandırılan göksel ejder, güneş ve ay sembolizminin yanı sıra dört ana yönü de simgelemektedir. Güney istikametini ifade eden kızıl ejder, Ateş Yıldız olarak adlandırılan Mars gezegeniyle ilişkilendirilmiştir ${ }^{80}$. Türkler tarafından evren olarak da adlandırılan ejderha, kâinatın sonsuz döngüsünü temsilen ekseri birbirine dolanmış çift ejder şeklinde betimlenmiştir (Çizim 11). İslam öncesi Türk sanatında erkek görünümlü, yılan benzeri esnek bir gövde ve tırtıklı bir yeleye sahip, iri boynuzlu, büyük gözlü, başında uçmasını sağlayan bir yumrusu bulunan, çıkıntılı bir burnu olan ve geleneksel olarak ateşler saçan bir yaratık olarak tasvir edilen Kök luu, Kızıl Saksağan yani gün ortasını temsil ettiğinde ise kuşa benzer ve kırmızı ile sarı renklere bürünmüş resmedilmiştir ${ }^{81}$. Bazı efsanelere göre yok edilmez olan ejderhaları ortadan kaldırmanın yegâne yolu, uyuyan ejderhadan koparılan tüyleri ateşe atılıp yakmaktır ${ }^{82}$.

Başlı başına ateşle ilgili yaratıklarının yanında ihtiva ettikleri özellikler itibariyle kısmen ateş unsuruyla bağlantılı kabul edilen yaratıklar da bulunmaktadır. Örneğin, farklı versiyonları olmakla birlikte ekseri insan başlı, bağa gövdeli, arslan pençeli ve kartal kanatlı olarak tasvir edilen Sfenks, (Çizim 12)) ateş, hava su ve toprak unsurları ile esrarlı güçlerin sembolü olarak kabul edilmektedir ${ }^{83}$. Bunun yanında kartal kafası ve pençeleri ile kanatlı ya da kanatsız bir arslanın gövdesine sahip Grifon (Çizim 13) da gökyüzünü, şafağın söküşünü ve güneşi temsil eden bir yaratık olarak hikmet, aydınlığa kavuşturma, kuvvet ve intikam özelliklerini barındırmasıyla da ateş unsuru ile bağlantılı kabul edilmiştir ${ }^{84}$.

\footnotetext{
${ }^{79}$ Y. Çoruhlu, age., 1995, s. 31.

${ }^{80}$ Bundan başka, doğu yönünü simgeleyen Sarı Ejder Toprak Yıldız olarak adlandırılan Satürn; batının sembolü olan Beyaz Ejder Altun Yıldız olarak adlandırılan Venüs; kuzeyde bulunan Kara Ejder ise Suv Yıdız olarak bilinen Merkür gezegenleriyle bağlantılı kabul edilmiştir. Bkz. Y. Çoruhlu, age., 1995, s. 49.

${ }^{81}$ E. Esin, age., 2004, s. 152, 163.

${ }^{82}$ Murat Uraz, Türk Mitolojisi, Düşünen Adam Yayınları, 2. Baskı, İstanbul, 1994, s. 163.

${ }^{83}$ Y. Çoruhlu, age., 1995, s. 32.

${ }^{84}$ Y. Çoruhlu, age., 1995, s. 16.
} 


\section{Sonuc}

Çok eski zamanlardan itibaren ateşi kullanan Türkler, ona kutsal ve büyüsel anlamlar yüklemiştir. Ancak kadim Türk inançlarına göre ateş bir tanrı değil, Tanrı'nın izni, bilgisi ve kudretiyle yaratılmış, insana öğretilmiş, çoğaltılmış, devam ettirilmiş, kişilik ve ruh sahibi canlı bir varlıktır. İlk ateş, göklerde yaşayan Tanrı'nın çakmağıyla çakılmış ve ailenin simgesi haline gelen ocağa yerleştirilmek üzere Ata'ya öğretilmiştir. Orta Asya Türk inancındaki ateş kültünün temelinde, Ata'nın yaktığı ateş ve annenin kurduğu ocak anlayışının yattığı görülmektedir. Türkler tarafından tıpkı ekmek ve su gibi bir nimet olarak kabul edilen ateşe kötü davranmak, kirletmek ve hakaret etmek kesin olarak yasaklanmıştır.

Kadim Türk topluluklarının dini ve gündelik hayatları, ateş kültü etrafinda gelişen ayin, tören ve uygulamalarla şekillenmiştir. Günlük hayatın vazgeçilmez öğelerinden biri olan ve sıradan işlerin halledilmesinde kullanılan küçük ateşin aksine kutsal törenlerde kullanılan Ulu Ateşi yakmanın belli bir yeri, zamanı, amacı ve şekli vardır. Buna bağlı olarak ateşin Tanrı tarafından elde ediliş şekli de Türklerin inanç dünyasında önem kazanmıştır. Ülgen'in ateşi iki taş marifetiyle yakması ancak çakmak taşıyla yakılan ateşin kutlu sayılmasına neden olmuş, ateşin yakılmasındaki ana malzemelerden biri olmasına bağlı olarak ağaç da ateş unsuru olarak önem kazanmıștır.

Gök Tanrı ekseni etrafında gelişen eski Türk inanç sisteminde göksel bir hediye olarak kabul edilen kutsal ateşle sürekli ve yakın temas halinde olan şamanlar ve demirciler de ateş kültü içerisinde ayrıcalıklı bir konum elde etmişlerdir. Ateşe hükmetme yeteneğine sahip olan bu kişiler yine kutsal ateş marifetiyle meydana çıkarılabilecek hayat, ölüm ve dünyaya dair karanlık sırlara vakıf; büyü yapmaya muktedir kabul edilmişlerdir. Gerek şaman gerekse de demircilerin erginlenme törenleri, ateşe hükmedebilme kudret ve yetkisinde olduklarını gösteren, farklı mahiyetteki ateşe temas ayinlerinden meydana gelmekteydi.

Ateş kültü bazı hayvanlar ya da mitolojik yaratıklarla da ilintili kabul edilmiştir. Ancak ateşin ortaya çıkışı ya da yaratılmasında etkili görülmeyen bu yaratıkların ekseri yardımcı roller üstlendikleri, Tanrıdan bir şekilde elde ettikleri bilgi vasıtasıyla ateşin insanlara ulaştırılmasında aracılık ettikleri anlaşılmaktadır. Ateşle ilgili efsane ve inanışlarda özellikle ateş kuşlarının ön plana çıtığı görülmektedir.

Tanrı ile insanı, iyi ile kötüyü, seçilmiş olanla sıradanı birbirinden ayıran fakat aynı zamanda da birbirine yakınlaştıran ateş, farklı coğrafya ve hayat 
İSLAM ÖNCESİ TÜRK KÜLTÜRÜNDE ATEŞ VE ATEŞE HÜKMEDENLER (MADDİ KÜLTÜR IZLLERI IŞIĞINDA)

koşullarında yaşayan Türk toplulukları arasında birleştirici bir unsur olmuştur.

\section{KAYNAKÇA}

Bachelard, Gaston, Ateşin Psikanalizi, Çev. Aytaç Yiğit, Bağlam Yayıncılık, Ankara, 1995.

Beydili, Celal, Türk Mitolojisi Ansiklopedik Sözlük, Çev. Eren Ercan, Yurt Kitap, Ankara, 2003.

Çoruhlu, Yaşar, Türk Sanatında Hayvan Sembolizmi, Seyran Kitap, İstanbul, 1995. , Türk Mitolojisinin Anahatları, Kabalcı Yayınevi, İstanbul, 2002.

Eliade, Mircea, Demirciler ve Simyacılar, Çev. Mehmet Emin Özcan, Kabalcı Yayınevi, İstanbul, 2011.

Esin, Emel, İslamiyetten Önceki Türk Kültür Tarihi ve İslama Giriş (Türk Kültürü El-Kitabl, II, Cild I/b'den Ayrı Basım), Edebiyat Fakültesi Matbaası, İstanbul, 1978.

, Türk Kozmolojisine Giriş, Kabalcı Yayınevi, İstanbul, 2001.

, Orta Asya'dan Osmanlyya Türk Sanatında İkonografik Motifler, Kabalc1 Yayınevi, İstanbul, 2004.

Türklerde Maddi Kültürün Oluşumu, Kabalcı Yayınevi, İstanbul, 2006.

Gumilöv, Lev Nikolayeviçen, Eski Türkler, Çev., Ahsen Batur, Birleşik Yayıncılık, İstanbul, 1999.

İnan, Abdülkadir, Eski Türk Dini Tarihi, Milli Eğitim Basımevi, İstanbul, 1976.

, Şamanizm, Türk Tarih Kurumu Basımevi, Ankara, 1986.

L. Ligeti, Bilinmeyen İ̧ Asya, Çev. Sadrettin Karatay, TTK., Ankara, 1986.

Mangaltepe, İsmail, Bizans Kaynaklarinda Türkler (Menandros Protektor ve Theophylaktos Simokattes), Doğu Kütüphanesi, İstanbul, 2009.

Murat Uraz, Türk Mitolojisi, Düşünen Adam Yayınları, İstanbul, 1994.

Ögel, Bahaeddin, Türk Mitolojisi (Kaynakları ve Açılklamalarılyla Destanlar), C. 1, Türk Tarih Kurumu Yayınları, Ankara, 1993.

, Türk Mitolojisi (Kaynakları ve Açıklamalarıyla Destanlar), C. 2, Türk Tarih Kurumu Yayınları, Ankara, 1995.

Roux, Jean-Paul, Eskiçağ ve Ortaçağda Altay Türklerinde Ölüm, Çev. Aykut Kazancıgil, Kabalcı Yayınevi, İstanbul, 1999.

, Türklerin ve Moğolların Eski Dini, Çev. Aykut Kazancıgil, Kabalcı Yayınevi, İstanbul, 2002.

Orta Asya Tarih ve Uygarlı, Çev. Lale Arslan, Kabalcı Yayınevi, İstanbul, 2006.

Şeşen, Ramazan, İslam Coğrafyacılarına Göre Türkler ve Türk Ülkeleri, TTK., Ankara, 2001 


\section{ÇİIIMLER}

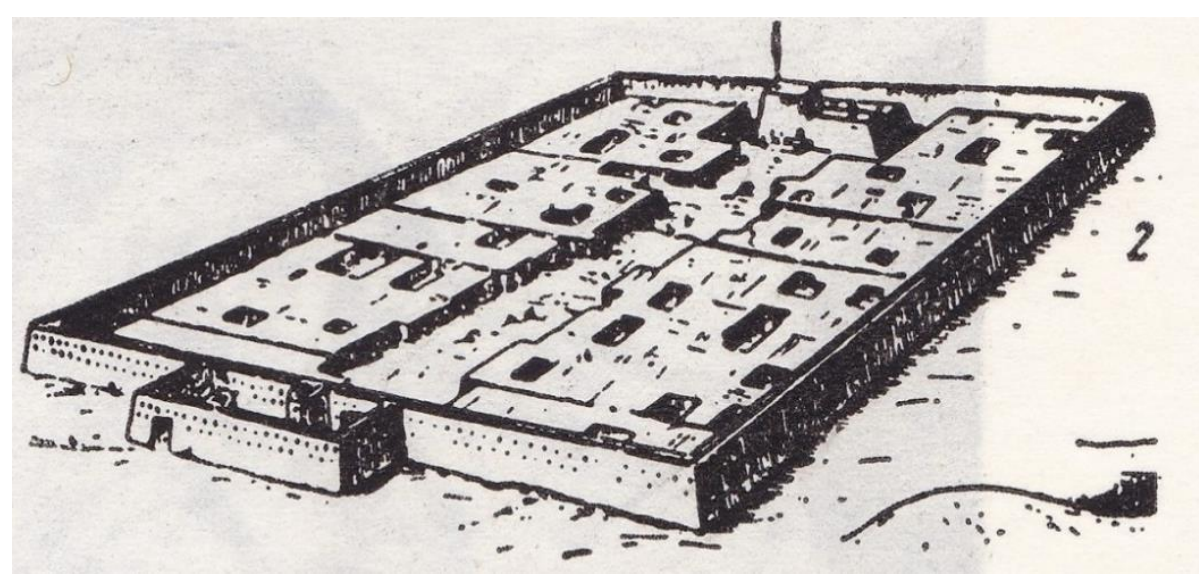

Çizim 1: Koy-Kırlgan Kalenin rekonstrüksiyonu (E.Esin'den)

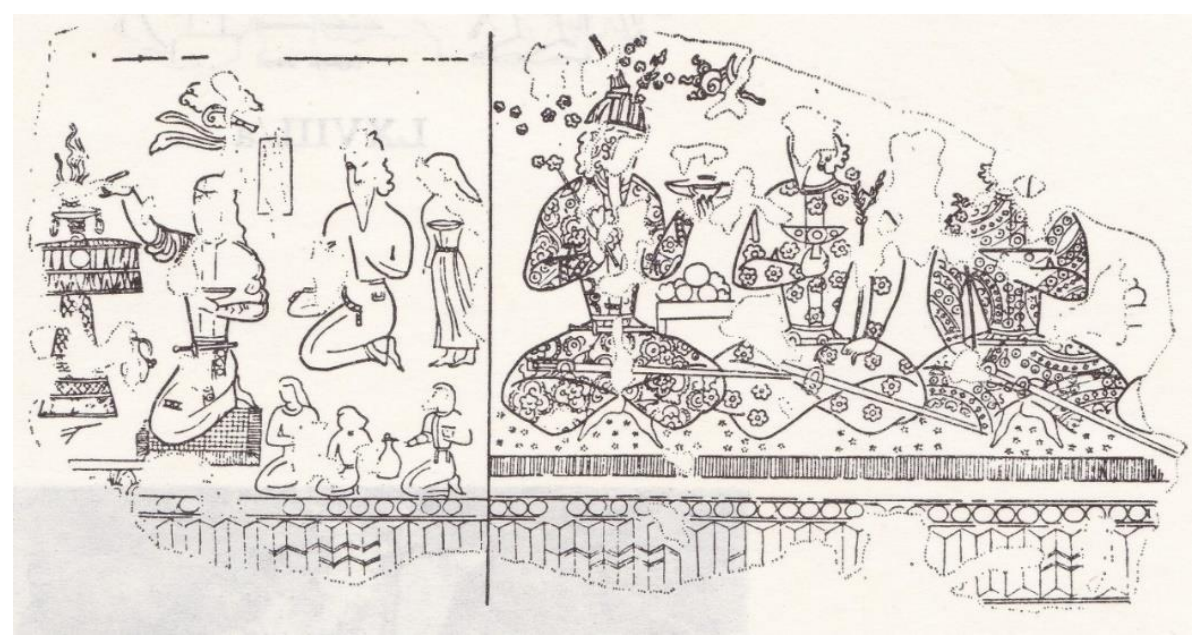

Çizim 2: Pencikent duvar resimlerinde ocak başında ant içmek merasimleri ile ilgili sahneler (E. Esin'den) 


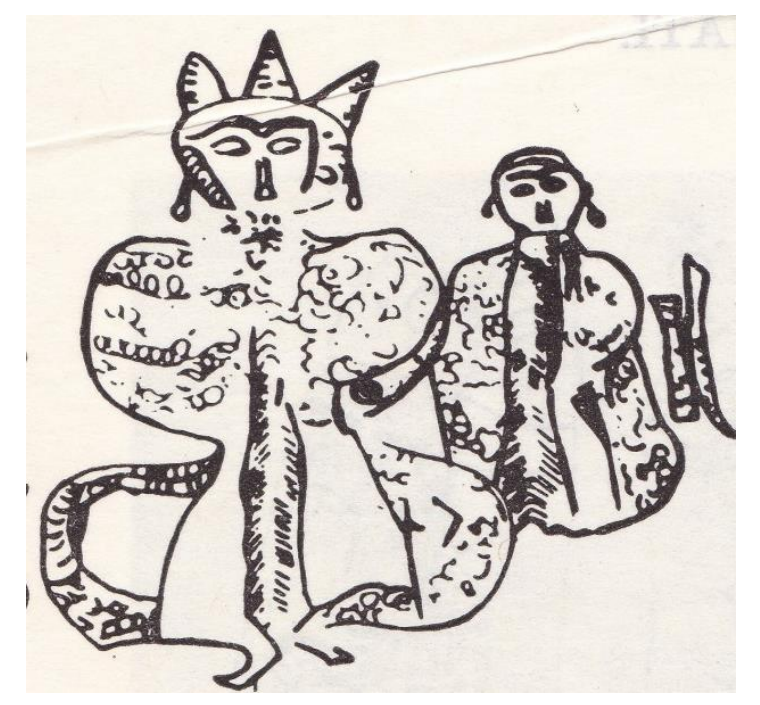

Çizim 3: Gök Türk devrinin başlangıcına ait bir taş oyma üzerinde tanrıça Umay tasviri (E. Esin'den)

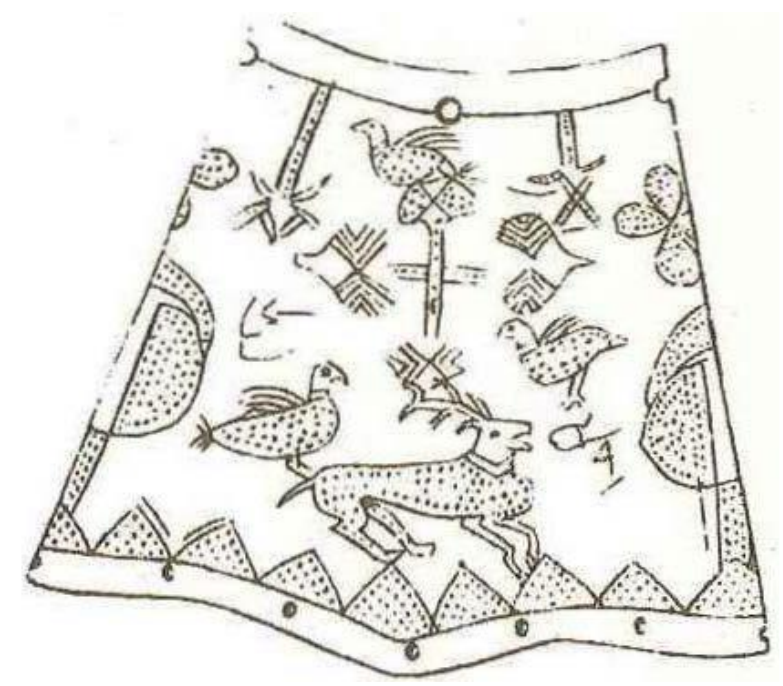

Çizim 4: VII-IX. Yüzyıllara ait kemik levha üzerinde üçgen şekilli dağlar. (E. Esin'den) 

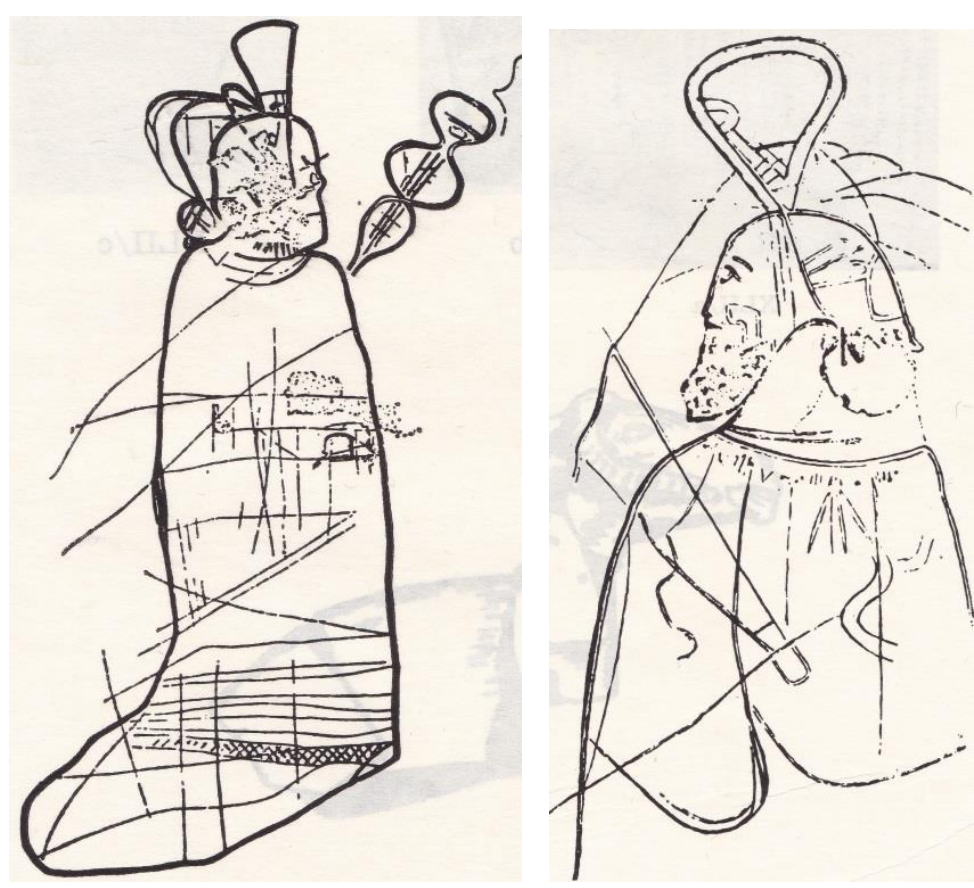

Çizim 5-6: Sibir'de Podkamen yanında taşa çizilmişs şaman tasvirleri (E. Esin'den)

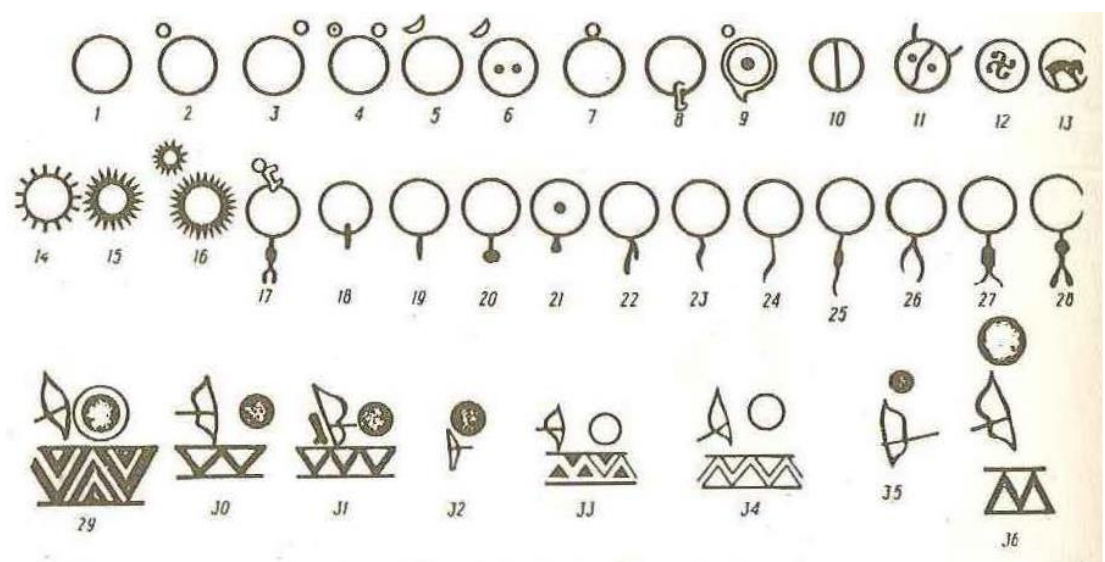

Çizim 7: Mezar anıtları üzerinde güneş, ateş, ayna ve 1şıkla ilgili ideogramlar (E. Esin'den) 


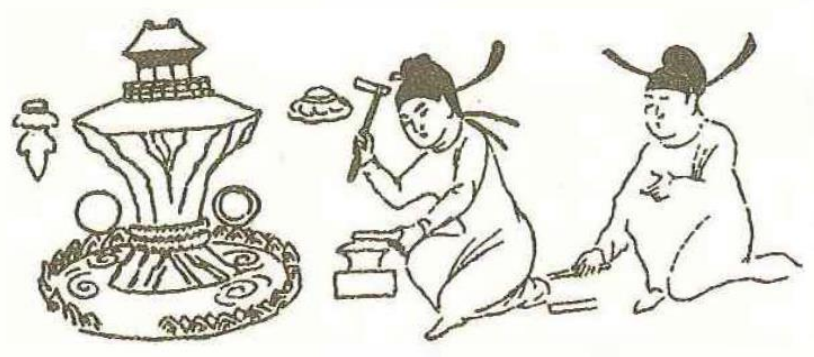

Çizim 8: VIII-IX. Yüzyıllara tarihlenen Bezeklik duvar resimlerinde Meru dağı ve demirciler (E. Esin'den)
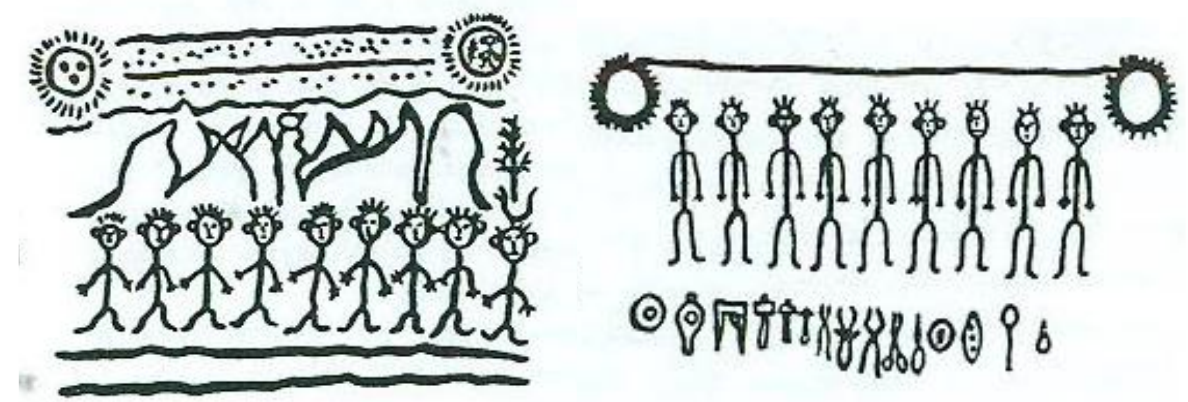

Çizim 9-10: Buryat Ongunu: Gökte güneş ve ay, ortada göğe uzanan dağlar, göksel demircinin dokuz oğlu ile sihirbaz demirciler ve onlara ait aletler. (B. Ögel'den) 


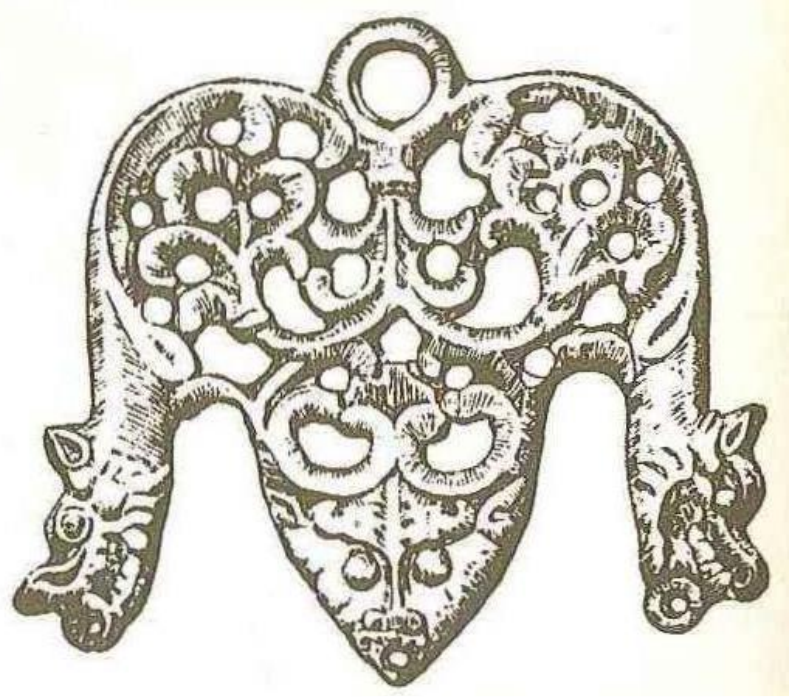

Çizim 11: VIII-IX. yüzyıllara tarihlenen çift ejder başlı bronz maske (E. Esin'den)

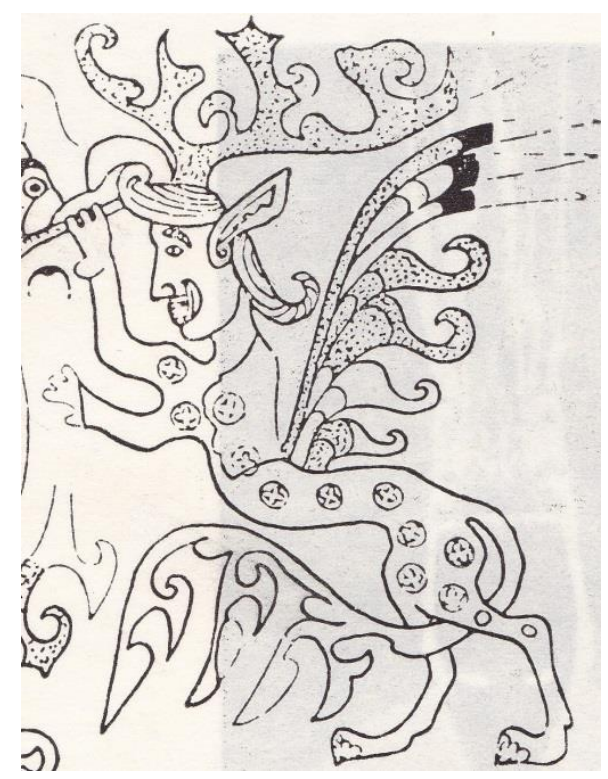

Çizim 12: Pazarık Kurganı'ndan çıkarılan keçe yaygı üzerinde sfenks tasviri (E.Esin'den) 
İSLAM ÖNCESİ TÜRK KÜLTÜRÜNDE ATEŞ VE ATEŞE HÜKMEDENLER (MADDİ KÜLTÜR İZLERİ IŞIĞINDA)

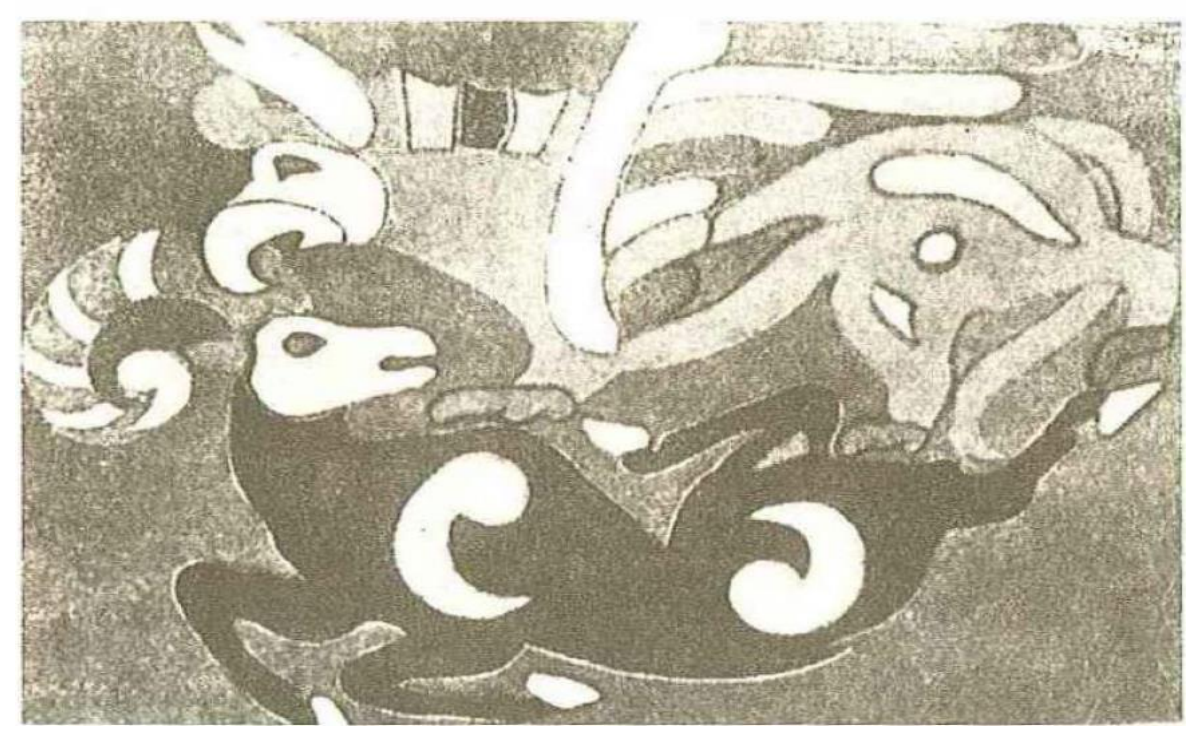

Çizim 13: Pazarık Kurganı'ndan çıkarılan bir eyer örtüsü üzerinde dağ keçisine saldıran girifon tasviri (E. Esin'den) 